\title{
Insertion of transposon Tn5 into a structural gene of the membrane-bound nitrate reductase of Thiosphaera pantotropha results in anaerobic overexpression of periplasmic nitrate reductase activity
}

\author{
Louise C. Bell, ${ }^{1}$ M. Dudley Page, ${ }^{1}$ Ben C. Berks, ${ }^{1,2}$ David J. Richardson ${ }^{1,2}$ \\ and StUART J. Ferguson ${ }^{1 *}$ \\ ${ }^{1}$ Department of Biochemistry, University of Oxford, South Parks Road, Oxford OX13QU, UK \\ ${ }^{2}$ School of Biological Sciences, University of East Anglia, Norwich NR4 7TJ, UK
}

(Received 22 April 1993; revised 7 July 1993; accepted 16 July 1993)

\begin{abstract}
Chlorate-resistant mutants of the denitrifying bacterium Thiosphaera pantotropha were generated by transposon Tn 5 mutagenesis. One class was deficient in membrane-bound nitrate reductase activity but retained a periplasmic nitrate reductase activity. Using transposon marker rescue it was shown that in one such mutant, M-6, the transposon was inserted in the membrane-bound nitrate reductase $\beta$ subunit structural gene (termed nar $H$ in order to be consistent with the nomenclature of the Escherichia coli major nitrate reductase operon). The translated sequence (total of 106 amino acids) from around the point of transposon insertion showed approximately $\mathbf{9 0 \%}$ amino acid identity with the $\beta$ subunits of the $E$. coli nitrate reductases. Under anaerobic growth conditions M-6 overproduced the periplasmic nitrate reductase activity allowing anaerobic growth with nitrate as electron acceptor. A regulatory link was inferred between the presence of the membrane-bound nitrate reductase and expression of the periplasmic nitrate reductase. This is the first demonstration of full denitrification in an organism possessing only a periplasmic nitrate reductase.
\end{abstract}

\section{Introduction}

Thiosphaera pantotropha $\dagger$ is reported to catalyse the complete series of denitrification reactions under aerobic conditions (Robertson \& Kuenen, 1983, 1984, 1990; Bell et al., 1990; Bell \& Ferguson, 1991; Moir et al., 1993; Berks et al., 1993). The organism has recently been shown to possess two respiratory nitrate reductases, one in the periplasm and the other associated with the cytoplasmic membrane (Bell et al., 1990). The catalytic

\footnotetext{
*Author for correspondence. Tel. +44865275240; fax +44865275259 .

Abbreviations: $\mathrm{BV}^{+}$, reduced benzyl viologen; $\mathrm{MV}^{+}$, reduced methyl viologen.
}

The EMBL accession number for the sequence reported in this paper is $\mathrm{Z} 26255$.

$\dagger$ Ludwig et al. (1993) have recently suggested, principally on the basis of 16SrRNA sequences, that $T$. pantotropha should be reclassified as Paracoccus denitrificans. While we agree that the organisms are very closely related, aspects of the biochemistry are distinct (unpublished data; manuscripts in preparation). Thus we think that reclassification is premature. We therefore continue to refer to the strain as $T$. pantotropha pending clarification by the International Committee of Systematic Bacteriology. site of the membrane-bound enzyme is located on the cytoplasmic face of the cytoplasmic membrane. Of the nitrate reductase activity in cells grown anaerobically with succinate as the carbon source, $80-90 \%$ is attributable to the membrane-bound enzyme. Oxygen inhibits reduction of nitrate in bacterial cells expressing the membrane-bound enzyme, apparently by indirectly restricting passage of nitrate across the cytoplasmic membrane (Alefounder \& Ferguson, 1980). The periplasmic enzyme accounts for all of the nitrate reductase activity of aerobically grown cells and is active in the presence of oxygen. Activity under aerobic conditions is therefore ascribed to the location of the enzyme in the periplasmic compartment.

Membrane-bound respiratory nitrate reductases have been purified and characterized from several bacteria, most notably and extensively from Escherichia coli (Stewart, 1988), but also from the denitrifier Paracoccus denitrificans (Craske \& Ferguson, 1986; Ballard \& Ferguson, 1987, 1988). In contrast, the occurrence of periplasmic nitrate reductases is much less widely documented and it is only for Rhodobacter sphaeroides f.sp. denitrificans, which also expresses a membranebound nitrate reductase (Byrne \& Nicholas, 1987), and some strains of Rhodobacter capsulatus that character- 
ization has been acheived to any significant extent (Alef \& Klemme, 1979; Satoh, 1981; McEwan et al., 1987; Richardson et al., 1990). The periplasmic nitrate reductases from $R$. capsulatus and T. pantotropha are similar with respect to two catalytic properties that distinguish them from the membrane-bound enzyme; resistance to inhibition by azide and inability to reduce chlorate (Bell et al., 1990; Ferguson et al., 1987).

The expression of two distinct respiratory nitrate reductases in $T$. pantotropha raises questions as to the mechanism of their differential regulation. It has recently been reported that expression of the periplasmic enzyme is higher following aerobic growth on reduced carbon substrates, such as butyrate or caproate, than on more oxidized substrates, such as malate or succinate (Richardson \& Ferguson, 1992). Further, the presence or absence of nitrate had no effect on aerobic expression of the periplasmic enzyme. Under anaerobic growth conditions it was found that nitrate reductase activity is predominantly due to the membrane-bound enzyme and is not significantly affected by the carbon growth substrate. Expression of the periplasmic enzyme thus remains low under anaerobic conditions regardless of the growth substrate. This is not true of the periplasmic nitrate reductase of $R$. capsulatus $\mathrm{N}^{2} 2 \mathrm{DNAR}^{+}$which is expressed to high levels during anaerobic phototrophic growth, the enzyme being further induced when highly reduced carbon sources are used for growth or if nitrate is available as an auxiliary electron acceptor (Richardson et al., 1990). Aerobic growth results in decreased expression of the periplasmic enzyme (D. J. Richardson \& S. J. Ferguson, unpublished results). Thus despite having similar catalytic properties the periplasmic nitrate reductases of $T$. pantotropha and $R$. capsulatus have distinct patterns of regulation. We reasoned that the differential regulation of the periplasmic nitrate reductase in $T$. pantotropha and $R$. capsulatus in response to oxygen might be a consequence in part of the capacity of $T$. pantotropha, but not $R$. capsulatus, to express a membrane-bound nitrate reductase. To investigate this theory we have isolated mutants of $T$. pantotropha deficient in the membrane-bound nitrate reductase and have examined the resultant effect on expression of the periplasmic nitrate reductase.

\section{Methods}

Thiosphaera pantotropha (strain LMD 82.5) was obtained from $\mathrm{Dr}$ L. A. Robertson, Department of Microbiology, Technical University of Delft, Delft, The Netherlands. Cells were cultured at $37^{\circ} \mathrm{C}$ on the minimal salts medium described by Robertson \& Kuenen (1984). The carbon source was $30 \mathrm{~mm}$-succinate and the concentration of nitrate when present was $25 \mathrm{~mm}$ for anaerobic growth and $5 \mathrm{~mm}$ for aerobic growth. The organism was grown aerobically in $50 \mathrm{ml}$ cultures in $300 \mathrm{ml}$ conical flasks. For anaerobic growth cultures were inoculated into $28 \mathrm{ml}$ Universal bottles containing $26 \mathrm{ml}$ medium and immediately sparged with nitrogen gas. Cells were harvested by centrifugation at mid-exponential phase $\left(\mathrm{OD}_{650}=0.6\right.$, equivalent to $0 \cdot 3-0.4 \mathrm{mg}$ dry wt cells $\mathrm{ml}^{-1}$ ). At this stage of growth the oxygen concentration in the aerobic cultures (measured in situ using a Jenway 9070 portable oxygen meter) was 180 to $200 \mu \mathrm{M}$. Cells were resuspended in nitrate-free growth medium for activity assays. Cells were fractionated as described by Bell et al. (1990). Nitrate respiration was measured under anaerobic and aerobic conditions using a nitrate electrode as previously described (Bell et al., 1990). Methyl- and benzyl-viologen-linked nitrate reductase assays were as described by Bell et al. (1990).

Transposon Tn5 mutagenesis was carried out according to the method of Chandra \& Friedrich (1986). Megaplasmid analysis was by the method of Eckhardt (1978). General cloning techniques were as described by Sambrook et al. (1989). DNA sequencing was performed using both Sequenase version 2.0 with $\left[{ }^{35} \mathrm{~S}\right] \mathrm{dATP}$ and the automated Pharmacia laser fluorescent system (A.L.F. Sequencer). The primer used was 5'-CGTTCAGGACGCTAC-3', complementary to bases 17-34 within the Tn 5 inverted repeat (Auerswald et al., 1980). Sequence analysis made use of the University of Wisconsin Genetics Computing Group software package release 7.2 (Devereux et al., 1984).

\section{Results}

\section{Selection and characterization of chlorate-resistant} Tn5-insertion mutants of $T$. pantotropha

The membrane-bound nitrate reductase of $T$. pantotropha, but not the periplasmic enzyme, will reduce chlorate to the toxic chlorite (Bell et al., 1990). Both aerobically and anaerobically grown $T$. pantotropha cells possess nitrate reductase activity, but tests of sensitivity to chlorate established that in cells grown aerobically in liquid culture there was resistance to $300 \mathrm{~mm}$ chlorate. In contrast, under anaerobic conditions growth was strongly retarded by $10 \mathrm{~mm}$-chlorate. Under the latter conditions the membrane-bound rather than the periplasmic enzyme is predominantly expressed, consistent with induction of the membrane-bound nitrate reductase being responsible for the sensitivity towards chlorate.

Growth on agar plates was also sensitive to $10 \mathrm{~mm}$ chlorate under anaerobic conditions. However, under aerobic conditions the sensitivity to chlorate increased relative to liquid cultures. Bacterial colonies growing on agar plates incubated aerobically experience low oxygen tensions and localized anaerobiosis. In $T$. pantotropha this results in low-level induction of the membranebound nitrate reductase (ascertained by picking colonies off plates, resuspending in phosphate buffer and determining the relative benzyl- and methyl-viologendependent nitrate reductase activities as described by Bell et al., 1990). Consequently, during aerobic growth on plates, although resistance was still observed to concentrations of chlorate of up to $100 \mathrm{~mm}$, increasing the chlorate concentration to $300 \mathrm{~mm}$ strongly inhibited growth.

At the outset of this work it was not clear whether mutants deficient in the membrane-bound nitrate reductase would be able to grow with nitrate under 
anaerobic conditions because of the recognized failure of wild-type cells to express the periplasmic enzyme to high levels under these growth conditions (Bell et al., 1990; Richardson \& Ferguson, 1992). On agar plates incubated aerobically a mutant deficient in membrane-bound nitrate reductase would still utilize oxygen for growth but would not produce chlorite from chlorate in the portion of the colony experiencing microanaerobiosis. It was therefore decided to seek chlorate-resistant mutants by plating transposon $\operatorname{Tn} 5$ transconjugants on plates containing $300 \mathrm{~mm}$ chlorate and to incubate these aerobically.

Several classes of chlorate-resistant Tn5-insertion mutants were isolated. The phenotype of one class, comprising three isolates obtained from 3000 colonies, will be described. Detailed presentation will be restricted to a representative mutant, strain M-6. Under aerobic conditions with succinate as carbon source growth of this class of mutants was similar to that of the wild-type cells (data for M-6 growth in liquid culture are given in Table 1). The mutants also grew under anaerobic conditions with succinate as carbon source and nitrate as electron acceptor though at a rate that was threefold lower than the wild-type (Table 1). This growth rate was unchanged by the presence of $50 \mathrm{~mm}$-chlorate (Table 1). In contrast, anaerobic growth of the wild-type cells was completely inhibited by $50 \mathrm{~mm}$-chlorate.

Anaerobic growth of the mutants, like growth of the wild-type, resulted in the evolution of gas suggesting that nitrate was still fully reduced to molecular dinitrogen by the mutants (the solubility of nitrous oxide is sufficiently high that it is very improbable that this was the major gaseous product). Anaerobic growth with nitrite or nitrous oxide as added electron acceptors was identical for the wild-type and mutant cells indicating that the mutants had no pleiotropic deficiency in the denitrification pathways terminating in nitrite or nitrous oxide reductases. The mutants grew indistinguishably from the wild-type cells; (i) chemoautotrophically with thiosulphate and bicarbonate; (ii) chemoautotrophically with formate as the sole carbon source; (iii) with xanthine as sole carbon and nitrogen source. These experiments indicate that there was no lesion in biosynthesis of the molybdopterin cofactor thought to be common to the nitrate reductases (Rajagopalan \& Johnson, 1992), most formate dehydrogenases (Harms et al., 1985), at least one necessary reaction of thiosulphate oxidation in $T$. pantotropha (Chandra \& Friedrich, 1986; Friedrich et al., 1986) and also some bacterial xanthine dehydrogenases (Hettrich et al., 1991; Johnson et al., 1991). Megaplasmid analysis of the mutant cells confirmed that the mutants were (a) T. pantotropha and $(b)$ had the full complement of megaplasmids found in the wild-type cells (Chandra \& Friedrich, 1986).
Table 1. Comparison of anaerobic and aerobic growth rates of wild-type $T$. pantotropha and the chlorate-resistant mutant $M-6$

The carbon source was succinate. Growth was followed by measuring the increase in light scattering at $650 \mathrm{~nm}$.

\begin{tabular}{|c|c|c|c|}
\hline \multirow[b]{2}{*}{ Growth conditions. } & \multicolumn{3}{|c|}{ Doubling time (min) } \\
\hline & $\begin{array}{c}\text { Anaerobic } \\
25 \mathrm{~mm}^{-\mathrm{NO}_{3}^{-}+} \\
50 \mathrm{~mm}-\mathrm{ClO}_{3}^{-}\end{array}$ & $\begin{array}{c}\text { Anaerobic } \\
25 \mathrm{~mm}-\mathrm{NO}_{3}^{-}\end{array}$ & $\begin{array}{c}\text { Aerobic } \\
5 \mathrm{mM}^{-\mathrm{NO}_{3}^{-}}\end{array}$ \\
\hline Wild-type & No growth & 80 & 55 \\
\hline M-6 & 240 & 240 & 55 \\
\hline
\end{tabular}

Table 2. Sensitivity to azide of rates of aerobic and anaerobic nitrate reduction in cells of wild-type T. pantotropha and mutant $M-6$ grown under aerobic and under anaerobic conditions

The steady-state oxygen concentration was $200 \mu \mathrm{M}$ in the aerobic experiments. Cells were resuspended in fresh nitrate-free growth medium.

\begin{tabular}{|c|c|c|c|c|}
\hline \multirow[b]{3}{*}{$\begin{array}{c}\text { Assay } \\
\text { conditions }\end{array}$} & \multicolumn{4}{|c|}{$\begin{array}{l}\text { Rate of nitrate reduction } \\
\text { [nmol nitrate reduced } \text { min }^{-1} \\
\left.(\text { mg cell protein })^{-1}\right]\end{array}$} \\
\hline & \multicolumn{2}{|c|}{ Wild-type } & \multicolumn{2}{|c|}{ M-6 } \\
\hline & $\begin{array}{l}\text { After } \\
\text { anaerobic } \\
\text { growth }\end{array}$ & $\begin{array}{l}\text { After } \\
\text { aerobic } \\
\text { growth }\end{array}$ & $\begin{array}{l}\text { After } \\
\text { anaerobic } \\
\text { growth }\end{array}$ & $\begin{array}{l}\text { After } \\
\text { aerobic } \\
\text { growth }\end{array}$ \\
\hline Anaerobic & 900 & 130 & 950 & 135 \\
\hline $\begin{array}{c}\text { Anaerobic }+ \\
20 \mu \mathrm{M} \text {-azide }\end{array}$ & 70 & 115 & 850 & 130 \\
\hline Aerobic & 90 & 95 & 750 & 100 \\
\hline $\begin{array}{l}\text { Aerobic }+ \\
20 \mu \mathrm{M} \text {-azide }\end{array}$ & 90 & 95 & 725 & 95 \\
\hline
\end{tabular}

The anaerobic growth, coupled with the resistance to chlorate, suggested that this class of chlorate-resistant mutant had retained the periplasmic nitrate reductase but lost the membrane-bound nitrate reductase. To investigate this possibility the properties of nitrate respiration by intact M-6 cells, grown anaerobically with succinate as carbon source and nitrate as electron acceptor were examined (Table 2). In the wild-type cells nitrate respiration was strongly inhibited by azide and oxygen, consistent with expression of the membranebound enzyme (Bell et al., 1990). In mutant M-6 the rate of nitrate respiration was comparable to that of the wildtype despite the much lower growth rate (Table 1). However, in contrast to the wild-type, this rate was not strongly depressed either by azide or oxygen. This is characteristic of the periplasmic enzyme and suggests that M-6 overexpresses this enzyme activity during 
Table 3. Comparison of the nitrate reductase activities of intact cells of wild-type and mutant $M-6$ cells of

$T$. pantotropha grown with succinate as carbon source using reduced methyl or benzyl viologen as electron donor

Cells were resuspended in $100 \mathrm{mM}-\mathrm{HEPES} / \mathrm{NaOH}, \mathrm{pH} 7 \cdot 3$.

\begin{tabular}{lcc}
\hline & \multicolumn{2}{c}{$\begin{array}{c}\text { Activity [nmol viologen oxidized } \text { min }^{-1} \\
\left.\text { (mg cell protein) }{ }^{-1}\right]\end{array}$} \\
\cline { 2 - 3 } Growth & $\mathrm{MV}^{+}$ & $\mathrm{BV}^{+}$ \\
conditions & & \\
\hline Wild-type & 30 & 215 \\
$\quad$ Anaerobic & 60 & 55 \\
$\quad$ Aerobic & & \\
Mutant M-6 & 235 & 240 \\
$\quad$ Anaerobic & 70 & 60 \\
Aerobic & & \\
\hline \hline
\end{tabular}

Table 4. Subcellular localisation of nitrate reductase activities from anaerobically grown wild-type $T$. pantotropha and mutant $M-6$

The total activity (sum of all fractions) was around $2700 \mathrm{nmol}$ $\mathrm{MV}^{+}$oxidized $\mathrm{min}^{-1}$ in both cases. This represented the total activity recovered from $30 \mathrm{mg}$ dry wt of anaerobically grown cells.

\begin{tabular}{lccc}
\hline \hline & \multicolumn{3}{c}{$\begin{array}{c}\text { Percentage } \mathrm{MV}^{+} \text {-nitrate oxidoreductase } \\
\text { activity recovered in: }\end{array}$} \\
\cline { 2 - 4 } Strain & Periplasm & Membranes & Cytoplasm \\
\hline Wild-type & 15 & 85 & 1 \\
Mutant M-6 & 100 & 0 & 0 \\
\hline \hline
\end{tabular}

anaerobic growth. The rates of nitrate respiration in aerobically grown wild-type and mutant M-6 cells were comparable but were sevenfold lower than in anaerobically grown cells. The insensitivity to oxygen and azide indicated that the activity was attributable to the periplasmic nitrate reductase in both cases.

In intact cells the membrane-bound nitrate reductase is more active with reduced benzyl viologen $\left(\mathrm{BV}^{+}\right)$than reduced methyl viologen $\left(\mathrm{MV}^{+}\right)$as electron donor, while the periplasmic nitrate reductase does not discriminate between the two (Bell et al., 1990). This is because $\mathrm{MV}^{+}$ is relatively ineffective at crossing the cytoplasmic membrane to interact with the catalytic subunit of the membrane-bound nitrate reductase (Jones \& Garland, 1977). As a consequence, in wild-type anaerobically grown cells the rate of $\mathrm{BV}^{+}$-dependent nitrate reduction was much greater than the $\mathrm{MV}^{+}$-dependent rate (Table $3)$. However, in anaerobically grown mutant M-6 the nitrate reductase activity was similar with either $\mathrm{BV}^{+}$or $\mathrm{MV}^{+}$as the non-physiological reductant. As the reduced viologens are direct electron donors to the nitrate reductases these experiments suggest that $M-6$ expresses high levels of the periplasmic nitrate reductase rather than the membrane-bound nitrate reductase when grown anaerobically. Both the wild-type and mutant M-6 showed similar levels of periplasmic nitrate reductase activity when grown aerobically with succinate as the carbon source (Table 3; see also Table 2 results). With both strains aerobic growth on the more reduced carbon source butyrate led to similar increased levels of periplasmic nitrate reductase activity (data not shown), in agreement with results previously reported for the wild-type (Richardson \& Ferguson, 1992). These experiments show that the pattern of expression of the periplasmic nitrate reductase activity during aerobic growth is not affected in mutant $\mathbf{M}-6$, i.e. expression of the periplasmic nitrate reductase activity in mutant M-6 is not constitutively derepressed.

\section{Studies on subcellular fractions of mutant $M-6$}

Wild-type $T$. pantotropha and mutant M-6, each grown anaerobically with nitrate as electron acceptor, were fractionated into periplasmic, cytoplasmic and membrane fractions (Table 4). Consistent with previous observations (Bell et al., 1990), $80 \%$ of the nitrate reductase activity of the wild-type cells was associated with the membrane fraction. In contrast, no nitrate reductase activity was detected with the membranes from mutant M-6. Instead the activity was associated exclusively with the periplasmic fraction and was sevenfold greater than that observed in wild-type periplasmic fractions.

Dithionite-reduced minus nitrate-oxidized spectra of membranes from anaerobically grown wild-type cells of $T$. pantotropha show reoxidation by nitrate of cytochrome(s) with absorption maxima at $557 \mathrm{~nm}$, characteristic of $b$-type cytochrome (Fig. 1c). By analogy with the membrane-bound nitrate reductases of $E$. coli and $P$. denitrificans (Sodergren et al., 1988; Ballard \& Ferguson, 1988) this nitrate-oxidizable cytochrome $b$ is probably associated with the integral membrane $\gamma$-subunit. Absence of an absorption change at $550 \mathrm{~nm}$ suggests that there is no oxidation of membrane $c$-type cytochromes by nitrate. The dithionite-reduced spectrum of membranes from anaerobically grown mutant M-6 was rather similar to that of the wild-type (compare Fig. $1 d$ with Fig. $1 a$ ). In contrast, no nitrate-dependent oxidation of either $b$ - or $c$-type cytochrome was evident for the M-6 membranes (Fig. 1e,f). These spectroscopic studies are consistent with the absence of membrane-bound nitrate reductase in mutant M-6.

Taken together, these experiments on subcellular fractions confirm the view derived from the whole cell experiments that under anaerobic growth conditions mutant M-6 overexpresses the periplasmic nitrate 

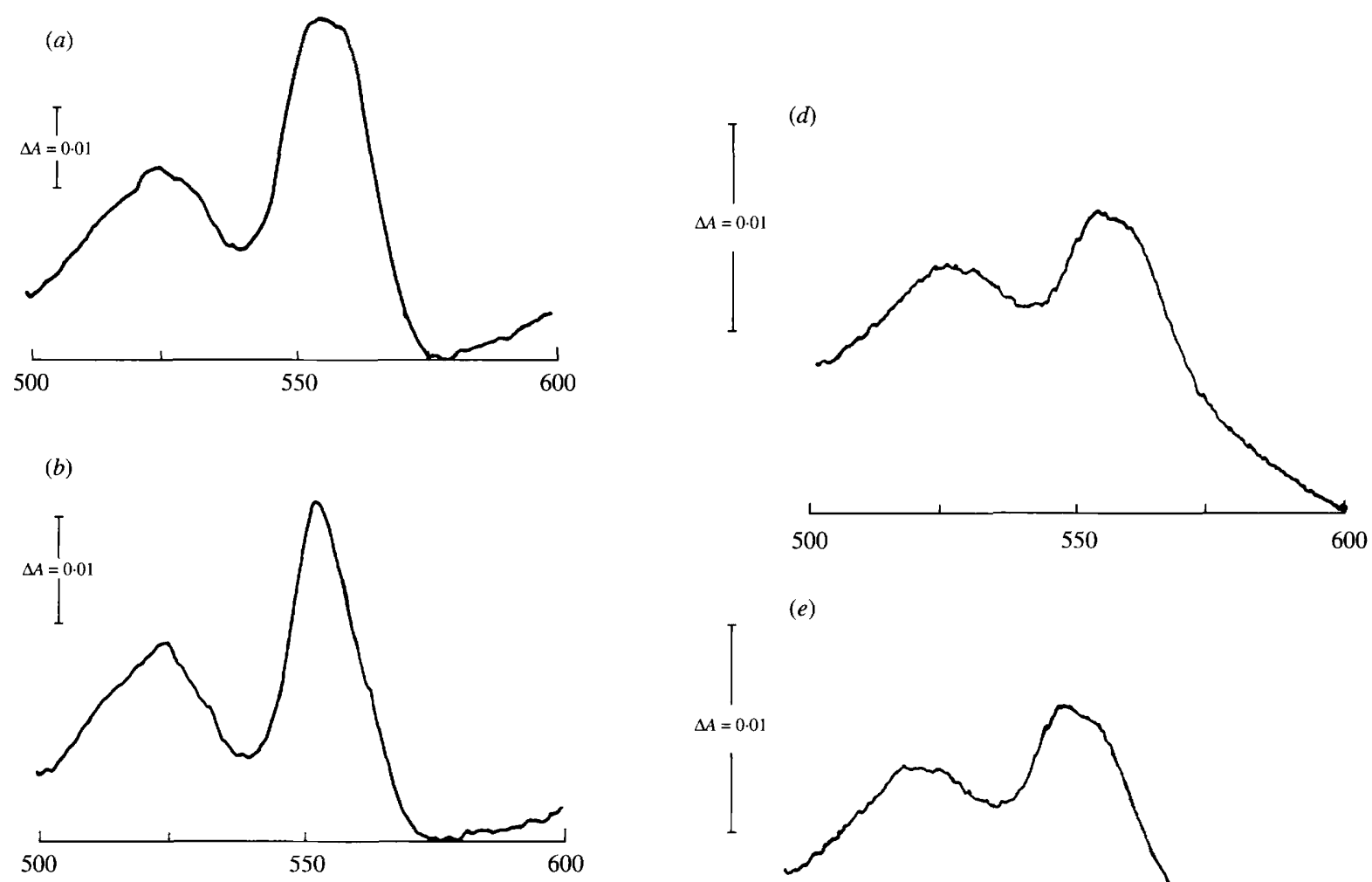

$(e)$
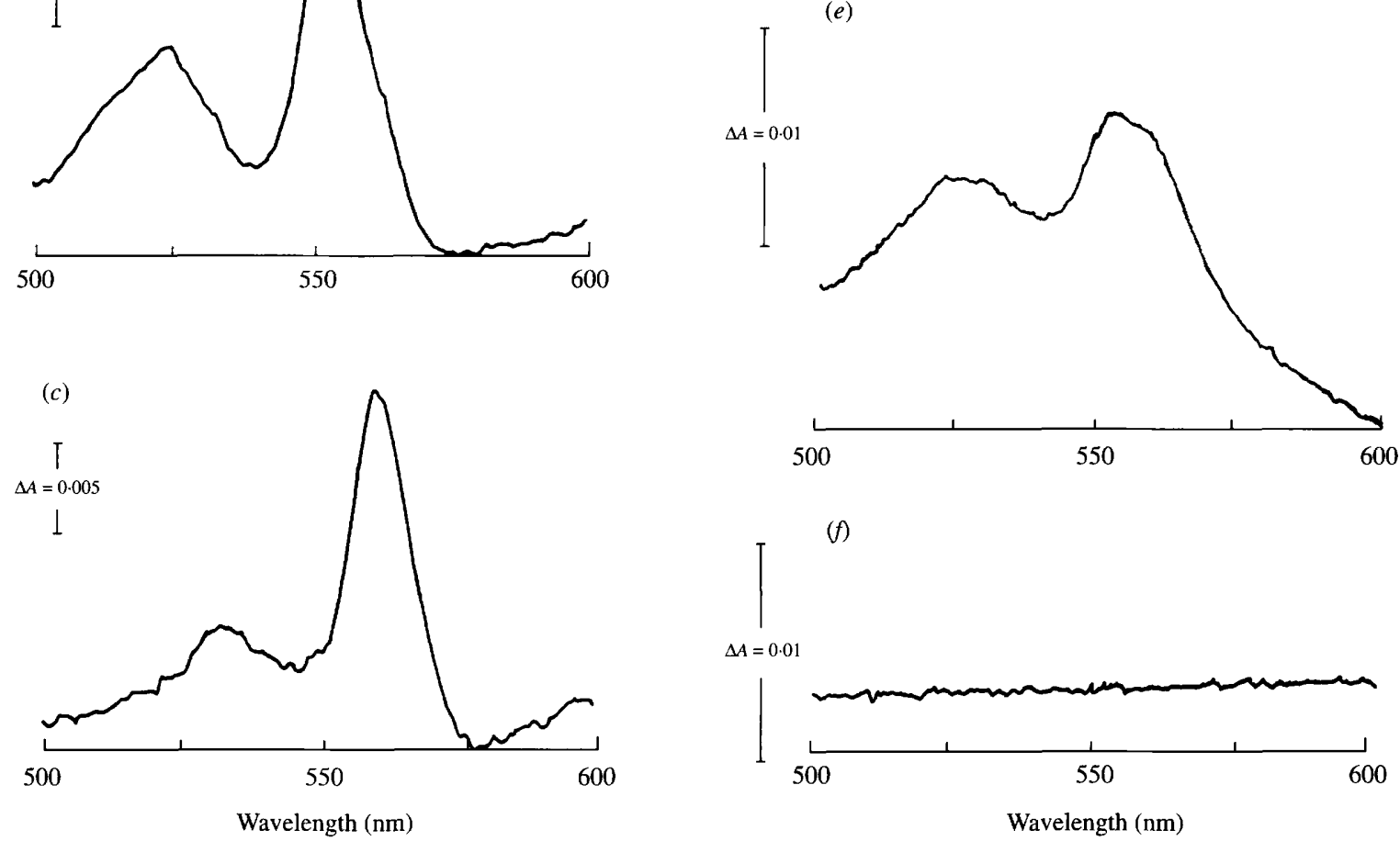

Fig. 1. Oxidation of membrane cytochromes by nitrate in wild-type $T$. pantotropha but not in mutant M-6, each grown anaerobically. Membranes were suspended in $100 \mathrm{mM}-\mathrm{Tris} / \mathrm{HCl}, \mathrm{pH} 7.8$, at a concentration of $2.5 \mathrm{mg}$ protein $\mathrm{ml}^{-1}(a-c)$ or $1.0 \mathrm{mg} \mathrm{protein} \mathrm{ml} l^{-1}$ $(d-f)$. (a) Wild-type membranes reduced with sodium dithionite; $(b)$ sample from (a) after addition of 1 mm-potassium nitrate; $(c)$ the difference spectrum obtained by subtracting the spectrum in $(b)$ from that in $(a)$, allowing the component(s) oxidized by nitrate to be identified; $(d)$ dithionite reduced membranes from mutant M-6; $(e)$ following addition of 1 mM-nitrate to the sample shown in $(d)$; $(f)$ the difference spectrum obtained by subtracting the spectrum in $(e)$ from that in $(d)$. Spectra were recorded at room temperature using an Aminco DW 2000 spectrophotometer.

reductase activity and does not express a functional membrane-bound nitrate reductase.

Identification of the locus of transposon insertion in mutant $M-6$

Southern blotting of mutant M-6 chromosomal DNA with the plasmid pSUP202: :Tn5 (Simon et al., 1983) that was used to generate the transposon mutants established the presence of a single integrated transposon, while Southern blotting with pSUP202 alone indicated the absence of vector DNA co-integration at the site of Tn5 insertion. T. pantotropha chromosomal DNA flanking the integrated transposon was cloned in pUC18 as a $13.5 \mathrm{~kb}$ EcoRI restriction fragment from total M-6 DNA using the transposon-encoded kanamycin resistance as a selectable marker. The size of the cloned insert corresponded to the size of the Tn5- 
-149 ACCTTCATGATGTATCTGCCGCGGCTGTGCGAGCATTGCCTCAACCCGGCCTGC ThrPheMetMetTyrLeuProArgLeuCysGluHisCysLeuAsnProAlaCys

-95 GTTGCCTCCTGCCCCTCGGGCGCGATCTACAAGCGCGAAGAGGACGGGGTGGTG ValAlaSerCysProSerGlyAlaIleTyrLysArgGluGluAspGlyValVaI

-41 CTGATCGACCAGGACAAGTGCCGGGGCTGGCGGATGTGTGTCTCGGGCTGCCCC LeUI leAspGInAspLysCysArgGlyTrpArgMetCysValserGIyCysPro

13 TACAAGAAGATCTATTACAACTGGTCGACCGGGAAGTCGGAAAAATGCATCCTG TyrLysLysI leTyrTyrAsnTrPSerThrGlyLysSerGluLysCysI leLeu

67 TGCTATCCGCGCCTTGAATCGGGCCAGCCCACGGTCTGCTCGGAAACCTGCGTC CysTyrProArgLeuGluSerGlyGlnProThrValCysSerGluThrCysVal

121 GGGCGCATCCGCTACCTGGGCGTGATGCTTTACGATGCCGACAAGATC GlyArgIleArgTyrLeuGlyValMetLeuTyrAspAlaAspLysI Ie
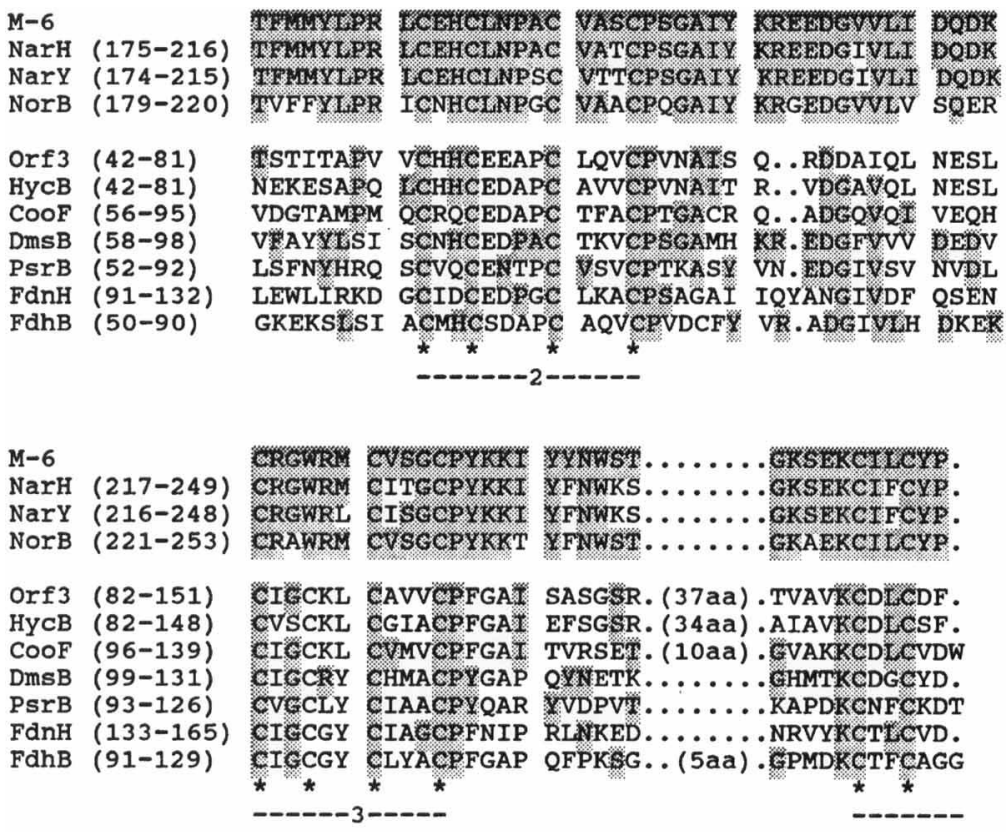

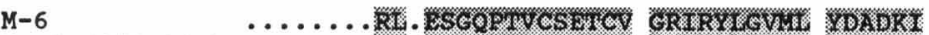

NarH (250-280) ........RI. EAEOPTVCSETCV CRTRVLCVLU WDADAT

NarY (249-279) …...RI. ESECPTVCSETCV GRTRYLEVLY YDADRT

NOrB $(254-284) \ldots \ldots \ldots$ RK. ESGHAPACFHSCV GRTRY TELVI FDADAT

Orf3 (152-179) ............PEGPACVRACP NQALRLITGD SLQROM

HYCB $(149-176) \ldots \ldots \ldots \ldots$ DE G GPACARMCP TKALHLVDNT DI KRVS

COOF $(140-171) \ldots \ldots \ldots$. ${ }^{2}$.

DmsB $(132-162) \ldots \ldots \ldots$ RV. AEGKKKPICVESCP LRALDFGPID ELRKKH

PSrB $(127-157) \ldots \ldots \ldots$ RU. ARGEEPACVTVCP TDALTFGDMS DPKSKK

FdnH $(166-196) \ldots \ldots$ RV.SVGCEPACVKẌKCP TGAIHFGTKK EMLELA

FdhB $(130-176) \cdot(16 a) \cdot R I$. AEGKVPVCAAMCS TKALLAGDSD SISLIY $*$ *
Fig. 2. DNA sequence and deduced amino acid sequence around the point of transposon Tn5 insertion in mutant M-6. The 9 base pairs duplicated at the point of transposon insertion are marked by asterisks; position zero in the DNA sequence is arbitrarily assigned to the central base of this duplicated sequence.
Fig. 3. Comparison of the protein sequence derived from the nucleic acid sequence around the point of transposon Tn 5 insertion in mutant M-6 with the amino acid sequences of the iron-sulphur protein subunits of the membrane-bound molybdopterin dinucleotide and other enzymes. Asterisks designate cysteines that are postulated to be involved in liganding iron-sulphur centres. Shading indicates residues that are identical between the M-6 and other sequences. The sequences are: NarH, E. coli membrane-bound nitrate reductase A (Blasco et al., 1989); NarY, E coli membranc-bound nitrate reductase $\mathrm{Z}$ (Blasco et al., 1990); NorB, Nitrobacter hamburgensis nitrite oxidase (Kirsten \& Bock, 1992); Orf3, E. coli (Andrews et al., 1991); HycB, E. coli formate hydrogenlyasc operon (Böhm et al., 1990); CooF, Rhodospirillum rubrum carbon monoxide dehydrogenase (Kerby et al., 1992); DmsB, E. coli dimethylsulphoxide reductase (Bilous et al., 1988); Psr B, Wolinella succinogenes polysulphide reductase (Krafft et al., 1992); FdnH, E. coli nitrate-inducible formate dehydrogenase (Berg $e t$ al., 1991); FidhB, W. succinogenes formate dehydrogenase (Bokranz et al., 1991). hybridizing $E c o$ RI fragment detected in the Southern analysis. For sequencing, M-6 chromosomal DNA flanking the $5^{\prime}$ end of the $\operatorname{Tn} 5$ element was subcloned as a $4.7 \mathrm{~kb} \mathrm{Bam} \mathrm{HI} \mathrm{fragment} \mathrm{containing} 1.7 \mathrm{~kb}$ of chromosomal DNA, and M-6 DNA flanking the Tn5 3 ' end was subcloned as a $4 \mathrm{~kb}$ Sall-EcoRI fragment containing 
approximately $1 \mathrm{~kb}$ of chromosomal DNA. M-6 DNA immediately adjacent to the transposon ends was then sequenced using a primer complementary to sequence within the Tn 5 inverted repeat. The sequence, obtained independently by both manual and automated sequencing, around the point of insertion is shown in Fig. 2. The expected 9 bp duplication with GC base pairs at positions 1 and 9 (Berg et al., 1983) is observed at the point of Tn5 integration. As shown in Fig. 3, translation of one of the reading frames around the point of insertion shows strong sequence similarity to the iron-sulphur protein $(\beta)$ subunits of membrane-bound molybdopterin dinucleotide enzymes, including those of the membranebound nitrate reductases of $E$. coli and the nitrite oxidase of Nitrobacter hamburgensis, for which a close structural relationship to the membrane-bound nitrate reductases has been expected (Ingledew \& Halling, 1976; Ballard \& Ferguson, 1987, 1988). It is clear from Fig. 3 that the similarity is greatest with the nitrate reductases/nitrite oxidase $; 91 \%, 90 \%, 75 \%$ amino acid identity and $98 \%$, $98 \%, 89 \%$ amino acid similarity to NarH, NarY, NorB respectively. Additionally, the pattern of insertions and deletions in the M-6 sequence relative to the other iron-sulphur proteins is the same as that found in the nitrate reductases (Fig. 3). Finally $\operatorname{Trp}_{220}$ (E. coli NarH numbering), the functional significance of which is discussed below and which is found only in the nitrate reductases/nitrite oxidase, is conserved in the M-6 sequence. We conclude from this sequence analysis that the transposon insertion in mutant $M-6$ is in the structural gene for the $\beta$-subunit of the membrane-bound nitrate reductase.

\section{Discussion}

The results of this study confirm that in wild-type cells of anaerobically grown $T$. pantotropha nitrate reductase activity is predominantly attributable to the membranebound enzyme. However, chlorate-resistant transposon Tn5-insertion mutants that do not express an active membrane-bound nitrate reductase retain wild-type levels of nitrate reductase when grown anaerobically, this activity being entirely attributable to the periplasmic nitrate reductase. As a result these mutants have a much higher capacity for aerobic nitrate respiration after anaerobic growth than do wild-type cells grown under identical conditions (Table 2).

In three-subunit membrane-bound molybdopterin dinucleotide enzymes, including the $E$. coli nitrate reductases, the genes coding for the three structural subunits are transcribed in the order molybdopterin dinucleotidecontaining catalytic $(\alpha)$ subunit (nar $G$ in the major $E$. coli nitrate reductase), iron-sulphur-centre-containing $(\beta)$ subunit $($ nar $H)$ and quinol/quinone-binding membrane- anchored $(\gamma)$ subunit (narI; for references see Fig. 3 legend). In mutant M-6 it was demonstrated by sequencing across the point of transposon insertion that the insert is in the structural gene for the $\beta$-subunit of the membrane-bound nitrate reductase. Given that the point of insertion corresponds to a position approximately in the middle of the $\beta$ polypeptides of the two nitrate reductases in $E$. coli, it is unlikely that a functional $\beta$ subunit is produced in mutant M-6. If the organization of the structural genes for the subunits of the membranebound nitrate reductase of $T$. pantotropha is the same as that found in all previously described membrane-bound molybdopterin dinucleotide enzymes, then the gene for the $\gamma$ subunit will be downstream of the point of transposon insertion in mutant M-6. As transposon Tn5 usually blocks the transcription of genes distal from the operon promoter (Berg, 1989) it is unlikely that any expression of the $\gamma$ polypeptide occurs. Thus we expect that only the $\alpha$ subunit of the membrane-bound nitrate reductase would be synthesized intact in this mutant. This is consistent with the observed phenotype of M-6: lack of membrane-bound nitrate reductase activity and an inability to link reduction of chlorate to physiological electron donors. Similarly, we can rationalize the observations of lack of nitrate-oxidizable $b$-type cytochrome in membranes from anaerobically grown cells of the mutant as being caused by the loss of transcription of the $b$-haem-binding $\gamma$-subunit structural gene. No reduced-viologen-dependent nitrate reductase activity was found in the cytoplasmic or membrane fractions of anaerobically grown mutant $M-6$ suggesting that if the $\alpha$ subunit is still synthesized in this mutant then either (i) reduced viologens cannot donate electrons directly to the $\alpha$ subunit, or (ii) the molybdopterin dinucleotide cofactor cannot be properly inserted in the isolated $\alpha$-subunit, or (iii) the isolated $\alpha$-subunit is susceptible to proteolysis or other inactivation in vivo.

The $\beta$ subunits of the membrane-bound molybdopterin-dinucleotide-containing enzymes contain four clusters of cysteine residues that are proposed to provide ligands to four $[4 \mathrm{Fe}-4 \mathrm{~S}]^{2+.1+}$ centres, or in the case of the nitrate reductases and nitrite oxidase three $[4 \mathrm{Fe}-4 \mathrm{~S}]^{2+.1+}$ and one $[3 \mathrm{Fe}-4 \mathrm{~S}]^{1+.0}$ centres (reviewed in Weiner et al., 1992). Although in defining the point of transposon insertion in mutant M-6 we have sequenced only a portion of the $\beta$ subunit this region covers three of the four cysteine clusters (see Fig. 3). All eleven cysteines conserved in this region in the membrane-bound nitrate reductases/nitrite oxidase are also found in the $T$. pantotropha sequence (Fig. 3). As each motif of four clustered cysteine residues is believed to provide three ligands for one iron-sulphur centre and one ligand for a second centre we deduce that four iron-sulphur centres are present in the $\beta$ subunit of $T$. pantotropha. The 
substitution of a tryptophan for a cysteine at position 220 (E. coli NarH numbering) in the nitrate reductase/ nitrite oxidase sequences relative to the other molybdopterin enzyme iron-sulphur protein sequences is probably associated with the presence of a $[3 \mathrm{Fe}-4 \mathrm{~S}]^{1+, 0}$ centre in these enzymes (Johnson et al., 1985; Rothery \& Weiner, 1991; Guigliarelli et al., 1992; Meincke et al., 1992; note that the converse substitution does not necessarily lead to a $[4 \mathrm{Fe}-4 \mathrm{~S}]^{2+, 1+}$ centre; Augier et al., 1993). The tryptophan-for-cysteine substitution is also apparent in the $T$. pantotropha $\beta$ subunit and so we predict that the $T$. pantotropha membrane-bound nitrate reductase will contain a $[3 \mathrm{Fe}-4 \mathrm{~S}]^{1+, 0}$ centre.

The sequence reported here is the first from any part of the membrane-bound nitrate reductase of a denitrifying bacterium. The very high sequence similarity between the $T$. pantotropha nitrate reductase partial sequence and the $E$. coli nitrate reductase sequences suggests that the membrane-bound nitrate reductases of denitrifying bacteria will turn out to be structurally very similar to those of the non-denitrifying enteric bacteria. Such a relationship had been indicated previously by similar subunit structure and antibody cross-reactivities (Craske \& Ferguson, 1986; Ballard \& Ferguson, 1988; Ballard et al., 1990). That insertion of a single transposon abolished all membrane-bound nitrate reductase activity in mutant M-6 means that, under the conditions investigated, $T$. pantotropha, unlike E. coli (Iobbi et al., 1987; Blasco et al., 1990), expresses only a single active membranebound nitrate reductase. Southern analysis with a fragment of the membrane-bound nitrate reductase operon derived from the $13.5 \mathrm{~kb} E c o$ RI M-6 fragment shows that there is only a single copy of the operon and is an indication against the possibility of a cryptic gene duplication (F. Outen, M. D. Page \& B. C. Berks, unpublished results).

T. pantotropha mutant M-6 is the first organism possessing only a periplasmic nitrate reductase that has been shown to denitrify. If the periplasmic nitrate reductase activity provided identical stoichiometry of proton translocation across the plasma membrane as the membrane-bound enzyme, then one might reasonably expect identical growth rates and growth yields in the mutant and wild-type unless the rate of nitrate reduction provided by the periplasmic enzyme were to be significantly less than that provided by the membrane-bound enzyme. The latter is demonstrated not to be the case here. Thus lower growth rates, and yields during denitrification under certain conditions (D. J. Richardson, unpublished observations), of mutant M-6 compared with the wild-type are plausibly a consequence of reduced energy conservation by the periplasmic nitrate reductase relative to the membrane-bound nitrate reductase in the span ubiquinol to nitrate. Such a difference in energetic coupling is in accord with current thinking. Quinol oxidation by the membrane-bound nitrate reductase generates a protonmotive force with a probable proton translocation stoichiometry of $2 \mathrm{H}^{+}: 2 \mathrm{e}^{-}$(Jones et al., 1980; Parsonage \& Ferguson, 1983; Nicholls \& Ferguson, 1992). In contrast, quinol oxidation by the periplasmic enzyme is postulated not to generate a protonmotive force since oxidation of quinol results in release of the two electrons, and presumably the two protons, in the periplasm, all of which are then consumed in the nitrate reduction reaction. This lack of energy conservation is consistent with the proposed role of the periplasmic nitrate reductase as an electron sink (McEwan et al., 1984; Richardson et al., 1988; Richardson \& Ferguson, 1992).

Mapping of the mutation in mutant M-6 to the structural gene for the membrane-bound nitrate reductase suggests that overexpression of the periplasmic nitrate reductase activity during anaerobic growth is a consequence of the loss of the membrane-bound nitrate reductase activity and rules out mutation in a regulatory protein as a cause. The elevated levels of periplasmic nitrate reductase activity in anaerobically grown mutant M-6 are similar to the levels of activity of the enzyme in wild-type cells grown aerobically on highly reduced carbon substrates (Richardson \& Ferguson, 1992). Failure to express the membrane-bound nitrate reductase (a quinol oxidase) could lead to a decrease in the steadystate redox potential of the quinol/quinone pool. A plausible explanation for the elevated expression of the periplasmic nitrate reductase in mutant M-6 is thus that it is mediated by a regulatory system that responds to changes in the redox state of the cell.

We wish to thank N. Karpovich-Tate, A. Reilly and A. Cavill for technical assistance. This research was supported by grants from SERC to S.J.F. (GRIE/70627 and GR/F48746), SERC/AFRC to S.J.F. and D.J.R. (GR/H12225) and a SERC quota studentship to L.C.B.

\section{References}

Alef, K. \& Klemme, J.-H. (1979). Assimilatory nitrate reductase of Rhodopseudomonas capsulata AD2: a molybdo-hemeprotein. Zeitschrift für Naturforschung 34c, 33-37.

Alefounder, P. R. \& Ferguson, S. J. (1980). The location of dissimilatory nitrite reductase and the control of dissimilatory nitrate reductase by oxygen in Paracoccus denitrificans. Biochemical Journal 192, 231-240.

Andrews, S. C., Harrison, P. M. \& Guest, J. R. (1991). A molecular analysis of the 53.3 minute region of the Escherichia coli linkage map. Journal of General Microbiology 137, 361-367.

Auerswald, E., Ludwig, G. \& Schaller, H. (1980). Structural analysis of Tn5. Cold Spring Harbour Symposia on Quantitative Biology 45, 107-113.

Augier, V., Guigliarelli, B., Asso, M., Bertrand, P., Frixon, C., Giordano, G., Chippaux, M. \& Blasco, F. (1993). Site-directed mutagenesis of conserved cysteine residues within the $\beta$ subunit of Escherichia coli nitrate reductase. Physiological, biochemical, and EPR characterization of the mutated enzymes. Biochemistry 32 , 2013-2023. 
Ballard, A. L. \& Ferguson, S. J. (1987). Molecular properties of the respiratory nitrate reductase of Paracoccus denitrificans. Biochemical Society Transactions 15, 937-938.

Ballard, A. L. \& Ferguson, S. J. (1988). Respiratory nitrate reductase from Paracoccus denitrificans. Evidence for two $b$-type haems in the $\gamma$ subunit and properties of a water-soluble active enzyme containing $\alpha$ and $\beta$ subunits. European Journal of Biochemistry 174, 207-212.

Ballard, A. L., MCEwan, A. G., Richardson, D. J., JaCkson, J. B. \& Ferguson, S. J. (1990). Rhodobacter capsulatus strain BK5 possesses a membrane bound respiratory nitrate reductase rather than the periplasmic enzyme found in other strains. Archives of Microbiology 154, 301-303.

Bell, L. C. \& Ferguson, S. J. (1991). Nitric and nitrous oxide reductases are active under aerobic conditions in cells of Thiosphaera pantotropha. Biochemical Journal 273, $423-427$.

Bell, L. C., Richardson, D. J. \& Ferguson, S. J. (1990). Periplasmic and membrane-bound respiratory nitrate reductases in Thiosphaera pantotropha: the periplasmic enzyme catalyzes the first step in aerobic denitrification. FEBS Letters 265, 85-87.

BeRG, D. E. (1989). Transposon Tn5. In Mobile DNA, pp. 185-210. Edited by D. E. Berg \& M. M. Howe. Washington, DC: American Society for Microbiology.

Berg, D. E., Schmandt, M. A. \& Lowe, J. B. (1983). Specificity of transposon Tn5 insertion. Genetics 105, 813-828.

Berg, B. L., Li, J., Heider, J. \& Stewart, V. (1991). Nitrate-inducible formate dehydrogenase in Escherichia coli K-12. I. Nucleotide sequence of the $f d n G H I$ operon and evidence that opal (UGA) encodes selenocysteine. Journal of Biological Chemistry 266, $22380-22385$.

Berks, B. C., Baratta, D., Richardson, D. J. \& Ferguson, S. J. (1993). Purification and characterization of a nitrous oxide reductase from Thiosphaera pantotropha. Implications for the mechanism of aerobic nitrous oxide reduction. European Journal of Biochemistry 212, 467-476.

Bilous, P. Y., Cole, S. T., ANderson, W. F. \& Weiner, J. H. (1988). Nucleotide sequence of the $d m s A B C$ operon encoding the anaerobic dimethylsulphoxide reductase of Escherichia coli. Molecular Microbiology 2, 785-795.

Blasco, F., Iobbi, C., Giordano, G., Chippaux, M. \& Bonnefoy, V. (1989). Nitrate reductase of Escherichia coli: completion of the nucleotide sequence of the nar operon and reassessment of the role of the $\alpha$ and $\beta$ subunits in iron binding and electron transfer. Molecular and General Genetics 218, 249-256.

Blasco, F., Iobbi, C., Ratouchniak, J., Bonnefoy, V. \& Chippaux, M. (1990). Nitrate reductases of Escherichia coli: sequence of the second nitrate reductase and comparison with that encoded by the narGHJI operon. Molecular and General Genetics 222, 104-111.

BöHM, R., SAUter, M. \& Böck, A. (1990). Nucleotide sequence and expression of an operon in Escherichia coli coding for formate hydrogenlyase components. Molecular Microbiology 4, 231-243.

Bokranz, M., Gutmann, M., Körtner, C., Kojro, E., Fahrenholz, F., LaUterbach, F. \& Kröger, A. (1991). Cloning and nucleotide sequence of the structural genes encoding the formate dehydrogenase of Wolinella succinogenes. Archives of Microbiology 156, 119-128.

BYRNE, M. D. \& Nicholas, D. J. D. (1987). A membrane-bound dissimilatory nitrate reductase from Rhodobacter sphaeroides f.sp. denitrificans. Biochimica et Biophysica Acta 915, 120-124.

Chandra, T. S. \& Friedrich, C. G. (1986). Tn5-induced mutations affecting sulfur-oxidizing ability (Sox) of Thiosphaera pantotropha. Journal of Bacteriology 166, 446-452.

Craske, A. \& Ferguson, S. J. (1986). The respiratory nitrate reductase from Paracoccus denitrificans. Molecular characterization and kinetic properties. European Journal of Biochemistry 158, 429-436.

DevereuX, J., Haeberli, P. \& Smithies, O. (1984). A comprehensive set of sequence analysis progams for the VAX. Nucleic Acids Research 12, 387-395.

ECKHARDT, T. (1978). A rapid method for the identification of plasmid deoxyribonucleic acid in bacteria. Plasmid 1, 584-588.

Ferguson, S. J., JACKSON, J. B. \& McEwan, A. G. (1987). Anaerobic respiration in the Rhodospirillaceae: characterization of pathways and evaluation of roles in redox balancing during photosynthesis. FEMS Microbiology Reviews 46, 117-143.
Friedrich, C. G., Meyer, O. \& Chandra, T. S. (1986). Molybdenumdependent sulfur oxidation in facultatively lithoautotrophic thiobacteria. FEMS Microbiology Letters 37, 105-108.

Guigliarelli, B., Asso, M., More, C., Augier, V., Blasco, F., Pommier, J., Giordano, G. \& Bertrand, P. (1992). EPR and redox characterization of iron-sulfur centers in nitrate reductases $\mathrm{A}$ and $\mathrm{Z}$ from Escherichia coli. Evidence for a high-potential and a lowpotential class and their relevance in the electron-transfer mechanism. European Journal of Biochemistry 207, 61-68.

Harms, N., De Vries, G. E., Maurer, K., Veltkamp, E. \& Stouthamer, A. H. (1985). Isolation and characterization of Paracoccus denitrificans mutants with defects in the metabolism of one carbon compounds. Journal of Bacteriology 164, 1064-1070.

Hettrich, D., Peschke, B., Tshisuaka, B. \& Lingens, F. (1991). Microbial metabolism of quinoline and related compounds. X. The molybdopterin cofactors of quinoline oxidoreductases from Pseudomonas putida 86 and Rhodococcus spec. B1 and of xanthine dehydrogenase from Pseudomonas putida 86. Biological Chemistry Hoppe-Seyler 372, 513-517.

INGLEDEW, W. J. \& Halling, P. J. (1976). Paramagnetic centres of the nitrite oxidizing bacterium Nitrobacter. FEBS Letters 67, 90-93.

IobBi, C., SANTini, C.-L., Bonnefoy, V. \& Giordano, G. (1987). Biochemical and immunological evidence for a second nitrate reductase in Escherichia coli K-12. European Journal of Biochemistry 168, 451-459.

Johnson, J. L., Chaudry, M. \& Rajagopalan, K. V. (1991). Identification of a molybdopterin-containing molybdenum cofactor in xanthine dehydrogenase from Pseudomonas aeruginosa. BioFactors 3, 103-107.

Johnson, M. K., Bennett, D. E., Morningstar, J. E., Adams, M. W. W. \& MoRTENSON, L. E. (1985). The iron-sulfur cluster composition of Escherichia coli nitrate reductase. Journal of Biological Chemistry 260, 5456-5463.

Jones, R. W. \& Garland, P. B. (1977). Sites and specificity of the reaction of bipyridilium compounds with anaerobic respiratory systems of Escherichia coli. Effects of permeability barriers imposed by the cytoplasmic membrane. Biochemical Journal 190, 79-94.

Jones, R. W., Lamont, A. \& Garland, P. B. (1980). The mechanism of proton translocation driven by the respiratory nitrate reductase complex in Escherichia coli. Biochemical Journal 190, 79-94.

Kerby, R. L., Hong, S. S., Ensign, S. A., Coppoc, L. J., Ludden, P. W. \& RoBerTS, G. P. (1992). Genetic and physiological characterization of the Rhodospirillum rubrum carbon monoxide dehydrogenase system. Journal of Bacteriology 174, 5284-5294.

Kirsten, K. \& Bock, E. (1992). Unpublished sequence. EMBL database accession number X66067.

Krafft, T., Bokranz, M., Klimmek, O., Schröder, I., Fahrenholz, F., KoJro, E. \& KröGer, A. (1992). Cloning and nucleotide sequence of the psrA gene of Wolinella succinogenes polysulphide reductase. European Journal of Biochemistry 206, 503-510.

Ludwig, W., Mittenhuber, G. \& Friedrich, C. G. (1993). Transfer of Thiosphaera pantotropha to Paracoccus denitrificans. International Journal of Systematic Bacteriology 43, 363-367.

McEwan, A. G., Jackson, J. B. \& Ferguson, S. J. (1984). Rationalization of the properties of nitrate reductases in Rhodopseudomonas capsulata. Archives of Microbiology 137, 344-349.

McEwan, A. G., Wetzstein, H. G., Meyer, O., Jackson, J. B. \& FERGUSON, S. J. (1987). The periplasmic nitrate reductase of Rhodobacter capsulatus; purification, characterization and distinction from a single reductase for trimethylamine- $N$-oxide, dimethylsulphoxide and chlorate. Archives of Microbiology 47, 340-345.

Meincke, M., Bock, E., Kastrau, D. \& Kroneck, P. M. H. (1992). Nitrite oxidoreductase from Nitrobacter hamburgensis: redox centers and their catalytic role. Archives of Microbiology 158, 127-131.

Moir, J. W. B., Baratta, D., Richardson, D. J. \& Ferguson, S. J. (1993). The purification of a $c d_{1}$-type nitrite reductase from, and the absence of a copper-type nitrite reductase from, the aerobic denitrifier Thiosphaera pantotropha; the role of pseudoazurin as an electron donor. European Journal of Biochemistry 212, 377-385.

Nicholls, D. G. \& Ferguson, S. J. (1992). Bioenergetics 2. London: Academic Press.

Parsonage, D. \& Ferguson, S. J. (1983). Reassessment of pathways of 
electron flow to nitrate reductase that are coupled to energy conservation in Paracoccus denitrificans. FEBS Letters 153, 108-112.

RaJaGopalan, K. V. \& Johnson, J. L. (1992). The pterin molybdenum cofactors. Journal of Biological Chemistry 267, 10199-10202.

Richardson, D. J. \& Ferguson, S. J. (1992). The influence of carbon substrate on the activity of the periplasmic nitrate reductase in aerobically grown Thiosphaera pantotropha. Archives of Microbiology 157, 535-537.

Richardson, D. J., King, G. F., Kelly, D. J., McEwan, A. G., FERGuSON, S. J. \& JACKSON, J. B. (1988). The role of auxiliary oxidants in maintaining redox balance during phototrophic growth of Rhodobacter capsulatus on propionate or butyrate. Archives of Microbiology 150, 131-137.

Richardson, D. J., McEwan, A. G., Page, M. D., Jackson, J. B. \& FERGUSON, S. J. (1990). The identification of cytochromes involved in the transfer of electrons to the periplasmic $\mathrm{NO}_{3}^{-}$reductase of Rhodobacter capsulatus and resolution of a soluble $\mathrm{NO}_{3}^{-}$-reductasecytochrome- $c_{552}$ redox complex. European Journal of Biochemistry 194, 263-270.

Robertson, L. A. \& KuENEN, J. G. (1983). Thiosphaera pantotropha gen. nov. sp. nov., a facultatively anaerobic, facultatively autotrophic sulphur bacterium. Journal of General Microbiology 129, 2847-2855.

Robertson, L. A. \& Kuenen, J. G. (1984). Aerobic denitrification: a controversy revived. Archives of Microbiology 139, 351-354.
Robertson, L. A. \& Kuenen, J. G. (1990). Combined heterotrophic nitrification and aerobic denitrification in Thiosphaera pantotropha and other bacteria. Antonie van Leeuwenhoek 57, 139-152.

ROTHERY, R. A. \& WEINER, J. E. (1991). Alteration of the iron-sulfur cluster composition of Escherichia coli dimethyl sulfoxide reductase by site-directed mutagenesis. Biochemistry 30, 8296-8305.

SambrooK, J., Fritsch, E. F. \& Maniatis, T. (1989). Molecular Cloning: a Laboratory Manual, 2nd edn. Cold Spring Harbor, NY: Cold Spring Harbor Laboratory.

SATOH, T. (1981). Soluble dissimilatory nitrate reductase containing cytochrome $c$ from a photodenitrifier, Rhodopseudomonas sphaeroides forma sp. denitrificans. Plant Cell Physiology 22, 443-452.

Simon, R., Priefer, U. \& Pühler, A. (1983). A broad host range mobilization system for in vivo genetic engineering: transposon mutagenesis in Gram negative bacteria. BioTechnology 1, 784-791.

Sodergren, E. J., Hsu, P.-Y. \& Demoss, J. A. (1988). Roles of the narJ and narI gene products in the expression of nitrate reductase in Escherichia coli. Journal of Biological Chemistry 263, 16156-16162.

STEWART, V. (1988). Nitrate respiration in relation to facultative metabolism in enterobacteria. Microbiological Reviews 52, 190-232.

Weiner, J. H., Rothery, R. A., Sambasivarao, D. \& Trieber, C. A. (1992). Molecular analysis of the dimethylsulfoxide reductase: a complex iron-sulfur molybdoenzyme of Escherichia coli. Biochimica et Biophysica Acta 1102, 1-18. 